WMJ (Warmadewa Medical Journal), Vol. 3 No. 1 Mei 2018, Hal. 21-26

\title{
Risiko Kandidiasis Serviks pada Wanita Usia Subur Akseptor Kontrasepsi Hormonal
}

\author{
Ni Wayan Armerinayanti ${ }^{1}$, Desak Putu Oki Lestari ${ }^{2}$ \\ ${ }^{1,2}$ Bagian Patologi Anatomi Fakultas Kedokteran dan Ilmu Kesehatan, Universitas Warmadewa \\ Email ${ }^{1}$ :armerinayantipranata@gmail.com
}

\begin{abstract}
Abstrak
Kontrasepsi Hormonal merupakan salah satu metode kontrasepsi yang paling diminati oleh Wanita Usia Subur (WUS) di Indonesia termasuk di Bali. Dewasa ini mulai timbul pro dan kontra mengenai penggunaan kontrasepsi hormonal terkait berbagai efek samping yang ditimbulkan, salah satunya dikatakan berkaitan dengan kandidiasis serviks. Tujuan penelitian ini adalah untuk mengetahui risiko kandidiasis serviks pada WUS akseptor kontrasepsi hormonal. Metode: Penelitian ini menggunakan rancangan case control yang disarangkan pada penelitian pap smear (nested case control). Kemudian akan dibandingkan seberapa besar efek paparan kontrasepsi hormonal antara kelompok kasus (kandidiasis serviks) dengan kelompok kontrol (non kandidiasis serviks) secara deskriptif analitik melalui uji statistik chi-square dengan $\mathrm{p}<0.05$ dan confident interval (CI) 95\%. Hasil: Terdapat perbedaaan yang bermakna terjadinya kandidiasis serviks antara akseptor kontrasepsi hormonal dengan non hormonal, dengan nilai $\mathrm{p}=0,000(\mathrm{p}<0.001), \mathrm{OR}=6,435, \mathrm{CI}=95 \%$. Diskusi: Adanya risiko kandidiasis servik pada akseptor kontrasepsi hormonal berkaitan dengan kandungan estrogen maupun progeteron yang mendukung pertumbuhan jamur spesies kandida
\end{abstract}

Kata Kunci: kandidiasis serviks, kontrasepsi hormonal, wanita usia subur

\section{Abstract}

[Risk of Services Candidates in Women Age Hospital Acceptor Hormonal Contracteption]

Hormonal contraceptive is one kind of contraceptive methods that mostly choosed by reproductive age women in Indonesia, especially in Bali. Nowadays, there was some polemic about hormonal contraceptive related it side effects, include cervical candidiasis. The aims of this study was to explore cervical candidiasis risk among reproductive woman hormonal contraceptive users. Methode: This study used nested case control design which then compare about hormonal contraceptive effect between cases group (cervical candidiasis) and control group (non cervical candidiasis) by descriptibe analysis of chi-square statistic test, $p<0.05$ and confident interval (CI) 95\%. Result: There was significant differenciate cervical candidiasis between hormonal contraceptive users and non hormonal contraceptive users, $p=0.000$ ( $p<0.001)$, OR $=6.345, C I=95 \%$. Discussion: Cervical candidiasis risk among hormonal contraceptive users related of estrogen and progesterone component which can supporting candida species growth.

Keywords: cervical candidiasis, hormonal contraceptive, reproductive age

\section{PENDAHULUAN}

Kandidiasis serviks merupakan penyakit infeksi pada mukosa serviks yang disebabkan oleh jamur spesies candida, terutama jenis candida albicans (C. albicans). Diperkirakan sekitar $20 \%$ populasi wanita di dunia tiap tahunnya mengalami kandidiasis serviks ${ }^{(19)}$. Angka prevalensi kandidiasis pada kelompok perempuan perilaku risiko tinggi adalah $11,2-28,9 \%$, angka tersebut justru lebih rendah dari kelompok perempuan perilaku risiko rendah (23). Sedangkan di Indonesia diperkirakan 20
$-30 \%$ wanita mengalami kandidiasis serviks. Kandidiasis merupakan 75\% penyebab gejala keputihan bagi wanita Indonesia, hal ini berbeda dengan hasil yang didapat di Negara Eropa. Hal ini berkaitan dengan tingkat kelembapan udara yang cukup tinggi di Indonesia yang mempermudah pertumbuhan jamur patogen oportunistik, seperti C. Albicans. Kandidiasis serviks seringkali menimbulkan keluhan yang bersifat subjektif maupun objektif ringan sampai berat. Keluhan subjektif utama yaitu gatal didaerah vulva, dan pada yang berat 
terdapat pula rasa panas, nyeri sesudah miksi dan dispaneuria. Keluhan objektif dapat berupa lesi eritema dan hiperemis hingga erosi di labia mayora, introitus vagina, vagina $1 / 3$ bawah dan serviks. Tanda khasnya adalah flour albus bewarna putih kekuningan disertai gumpalan-gumpalan seperti susu ${ }^{(5)}$.

Terdapat beberapa faktor risiko terjadinya pertumbuhan berlebih jamur C. albicans sehingga akhirnya menimbulkan kandidiasis, yaitu terkait faktor host, agen infeksi dan lingkungan. Faktor host di antaranya kegemukan, defisiensi imunitas tubuh, diabetes melitus, kehamilan, pemakaian kontrasepsi hormonal khususnya oral, pemakaian larutan pembersih area kewanitaan dan infeksi kronik dalam servik atau vagina. Faktor lingkungan antara lain iklim yang panas dan lembab serta higienitas yang buruk. Sedangkan faktor agennya berupa kemampuan internal jamur dalam melakukan adhesi maupun berkompetisi dalam perebutan nutrisi dan pelepasan metabolit yang bersifat toksik terhadap mukosa $(4,6)$.

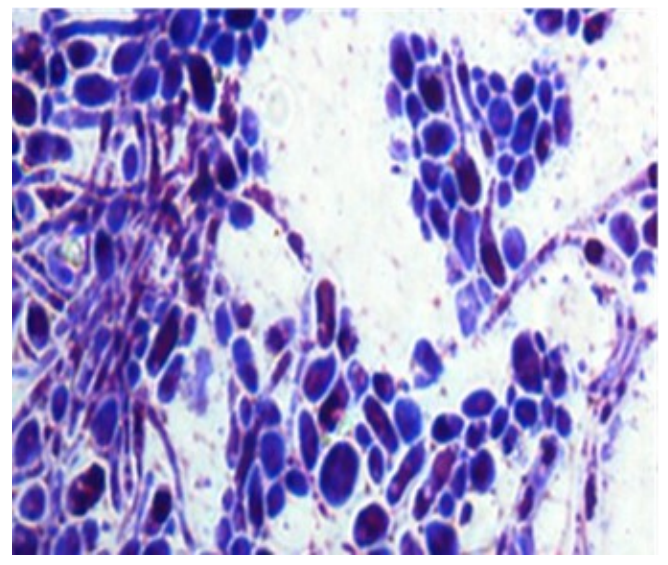

Gambar 1.1 Mor fologi Candida Albicans pada Pemeriksaan Pap Smear ${ }^{(14)}$

Sebagai salah satu faktor risiko host terinfeksi kandidiasis serviks, maka mulai muncul penelitian yang menelusuri dampak penggunaan kontrasepsi hormonal terhadap timbulnya kandidiasis serviks. Kontrasepsi adalah segala macam alat atau cara yang digunakan oleh satu pihak atau kedua belah pihak untuk menghindari atau mencegah terjadinya kehamilan sebagai akibat pertemuan sel sperma dan sel telur (ovum) yang sudah matang ${ }^{(26)}$. Kontrasepsi juga merupakan teknik-teknik untuk menjarangkan atau membatasi kehamilan. Keberhasilan dalam pemakaian kontrasepsi merupakan salah satu bukti keberhasilan program KB Nasional ${ }^{(24)}$. Sedangkan Kontrasepsi hormonal merupakan kontrasepsi yang menggunakan efek hormon progesteron atau kombinasi antara estrogen dosis rendah dan progesteron ${ }^{(7,16)}$. Kontrasepsi hormonal terdiri dari kontrasepsi suntik, pil, dan implan. Ketiga kontrasepsi tersebut memiliki kandungan hormon progesteron dan estrogen sintetik, tetapi kadar hormon dari masing-masing jenis berbeda-beda ${ }^{(25)}$. Selama ini diketahui bahwa ketidakseimbangan hormonal terutama akibat peningkatan hormon estrogen mampu meningkatkan pertumbuhan dan produksi toksin serta fase germinasi dari spesies candida yang merupakan agen jamur komensal penyebab kandidiasis $^{(9,10,18)}$.

Hingga kini kontrasepsi hormonal ikut berperan dalam pengendalian kehamilan sehingga metode ini tetap diminati kelompok wanita usia subur (WUS). WUS adalah wanita yang keadaan organ reproduksinya berfungsi dengan baik antara umur 20-45 tahun. Puncak kesuburan ada pada rentang usia 20-29 tahun. Pada usia ini wanita memiliki kesempatan 95\% untuk hamil $^{(22)}$. Di sisi lain, diketahui bahwa kontrasepsi hormonal memiliki berbagai efek samping yaitu; gangguan haid, peningkatan berat badan, dan bahkan mempengaruhi kualitas kesuburan ${ }^{(15)}$.Permasalahan yang saat ini muncul adalah hubungan kontrasepsi hormonal dengan kandidiasis serviks. Beberapa penelitian sebelumnya menunjukkan tidak adanya kaitan antara pemakaian kontrasepsi hormonal dengan kandidiasis vagina ${ }^{(8,10,18)}$ sedangkan penelitian lainnya menunjukkan hasil yang sebaliknya ${ }^{(6,8)}$. Adanya pro kontra mengenai efek kontrasepsi hormonal juga berkontribusi pada persentase akseptor kontrasepsi hormonal di Bali yang pada tahun 2013 menunjukkan penurunan pengguna akseptor kontrasepsi hormonal menjadi 
sebanyak $37,8 \%{ }^{(11)}$.

Mengingat masih adanya pro kontra terkait pemakaian kontrasepsi hormonal terhadap kejadian kandidiasis serviks maka penelitian ini penting dilaksanakan sehingga selanjutnya dapat dianalisis hubungan penggunaan kontrasepsi hormonal dengan kandidiasis servik.

\section{METODE PENELITIAN}

Penelitian ini menggunakan rancangan case control yang disarangkan pada penelitian pap smear (nested case control). Pada penelitian ini akan dibandingkan seberapa besar efek paparan kontrasepsi hormonal antara kelompok kasus (kandidiasis serviks) dengan kelompok kontrol (non kandidiasis serviks). Penelitian ini dilaksanakan selama 6 bulan pada bulan Juni 2017-November 2017 di Laboratorium Biomedik Fakultas Kedokteran dan Ilmu Kesehatan Universitas Warmadewa. Sampel dihitung berdasarkan rumus berikut:

$$
\mathrm{n}=\left(\frac{\mathrm{z} \alpha / 2+\mathrm{z} \beta \sqrt{\mathrm{PQ}}}{(\mathrm{P}-1 / 2)}\right)^{2}
$$

Sehingga didapatkan jumlah sampel kasus yang digunakan adalah 30 sampel. Sedangkan jumlah sampel kontrol berdasarkan rasio kasus: kontrol $=1: 2$ adalah 60 sampel. Sampel merupakan preparat pap smear yang dikumpulkan dari beberapa laboratorium patologi, diantaranya laboratorium patologi RSUD Sanjiwani, RSUD Karangasem dan RS Balimed. Laboratorium tersebut dipilih karena memiliki kerjasama dengan institusi penulis dan salah satunya juga menjadi tempat praktek penulis. Sebelum pengambilan sampel pap smear, diberikan formulir yang juga menunjang data penelitian dan informed consent untuk persetujuan tindakan pap smear.

Data selanjutnya dianalisis secara deskriptif analitik dengan menggunakan uji statistik chi-square untuk membandingkan risiko paparan kontrasepsi hormonal antara kelompok kasus (kandidiasis serviks) dengan kelompok kontrol (non kandidiasis serviks). Uji kemaknaan ditentukan pada $p$
$<0,05$. Presisi data ditentukan dengan nilai Confident Interval (CI) 95\%.

\section{HASIL DAN PEMBAHASAN}

Sampel penelitian menunjukkan rentang usia akseptor kontrasepsi lebih dari $75 \%$ pada usia subur yaitu antara $25-45$ tahun dengan rerata usia 25,02 $\pm 0,47$ tahun dengan persentase yang hampir imbang antara akseptor kontrasepsi hormonal $(52,2 \%)$ dan non hormonal $(47,8 \%)$. Hasil penelitian ini juga membuktikan bahwa sasaran program KB sudah sesuai dimana mayoritas akseptor $\mathrm{KB}$ adalah wanita usia produktif yaitu antara 20 sampai 49 tahun.

Rentang usia kasus kandidiasis maupun non kandidiasis juga antara usia 25-45 tahun. Melalui analisis kemaknaan dengan uji chi square, didapatkan beda rerata antar ketiga kelompok tidak bermakna $(\mathrm{p}=0,719$; $\mathrm{p}>0.05$ ) (Tabel 1).

\begin{tabular}{|c|c|c|c|c|}
\hline & \multicolumn{4}{|c|}{ Kasus } \\
\hline & & Kandidiasis & Non Kandidiasis & Total \\
\hline & $<25$ & 4 & 5 & 9 \\
\hline Usia & $25-45$ & 22 & 48 & 70 \\
\hline & $>45$ & 4 & 7 & 11 \\
\hline Total & & 30 & 60 & 90 \\
\hline
\end{tabular}

Sehingga, pemilihan jenis kontrasepsi tidak berkaitan dengan usia akseptor. Hal ini juga sesuai dengan penelitian sebelumnya dimana menyebutkan bahwa pemilihan kontrasepsi ditentukan oleh riwayat haid atau adanya gangguan haid akibat pengaruh hormonal, status kesehatan akseptor, serta hasil pemeriksaan fisik dan panggul akseptor ${ }^{(1,2)}$.

Untuk mengetahui perbedaan angka kejadian kandidiasis serviks antara akseptor kontrasepsi hormonal dengan non hormonal maka dilakukan analisis chi square sesuai tabel 2 dan tabel 3.

Tabel 2. Angka kejadian kandidiasis serviks antara akseptor kontrasepsi hormonal dengan non hormonal 


\begin{tabular}{ccccc} 
& \multicolumn{4}{c}{ Kontrasepsi } \\
& & Hormonal & Non Hormonal & Total \\
Kasus & Kandidiasis & 24 & 6 & 30 \\
& $\begin{array}{c}\text { Non Kan- } \\
\text { Tidiasis }\end{array}$ & 23 & 37 & 60 \\
Total & & 47 & 43 & 90
\end{tabular}

Tabel 3. Hasil analisis Chi-Square hubungan kandidiasis serviks dengan penggunaan kontrasepsi hormonal

\begin{tabular}{lccc}
\multicolumn{4}{c}{ Chi-Square Tests } \\
& & \multicolumn{3}{c}{ Asymp. Sig. (2- } \\
& Value & df & sided) \\
Pearson Chi-Square & 14.689 & 2 & .001 \\
Likelihood Ratio & 15.659 & 2 & .000 \\
Odds Ratio & 6.435 & &
\end{tabular}

Hasil analisis tersebut menunjukkan perbedaaan yang bermakna terjadinya kandidiasis serviks antara akseptor kontrasepsi hormonal dengan non hormonal, dengan nilai $p=0,000(p<0.001), C I=95 \%$ dan $\mathrm{OR}=6,435$. Penelitian ini sesuai juga dengan beberapa penelitian sebelumnya yang menunjukkan hasil serupa ${ }^{(4,6,13,19)}$.

Pada beberapa penelitian tersebut didapatkan bahwa kandungan estrogen maupun progesteron yang terdapat pada kontrasepsi hormonal dapat meningkatkan glikogen pada serviks dan vagina yang selanjutnya diubah menjadi asam laktat oleh laktobasilus. Suasana asam ini merupakan suasana pendukung bagi pertumbuhan jamur terutama spesies Candida ${ }^{(13,19)}$. Selain itu diketahui juga pada jamur Candida juga terdapat reseptor estrogen yang memiliki afinitas yang kuat terhadap komponen 17- $\beta$-estradiol dari estrogen. Ikatan ini kemudian memicu transkripsi protein PDR16 yang selanjutnya meningkatkan aktivitas PLD (Posfolipid D) yang berperan penting mengubah ragi menjadi bentuk hifa (germ tube formation) ${ }^{(4,6)}$.

Pada penelitian lain, didapatkan bahwa kerja estrogen pada jamur lebih dipengaruhi oleh efek estrogen dalam mengaktivasi beberapa jenis respon stress pada candida (pelepasan protein heat-stress protein/hsp) yang selanjutnya melalui jalur MAP Kinase memicu perubahan morfologi jamur ke dalam bentuk hifa. Estrogen juga mempengaruhi aspek virulensi lain dari candida, diantaranya meningkatkan kemampuan adesi jamur pada epitel saluran reproduksi, kolonisasi hifa dan menimbulkan efek imunosupresif pada host dengan menekan kerja Th1 dalam mekanisme pertahanan terhadap jamur ${ }^{(6)}$.

\section{KESIMPULAN}

Penggunaan kontrasepsi hormonal pada wanita usia subur meningkatkan risiko terjadinya kandidiasis serviks. Hal ini dapat berkaitan dengan kandungan estrogen maupun progesteron pada kontraepsi hormonal yang mendukung pertumbuhan jamur terutama spesies Candida.

Diharapkan nantinya dilakukan penelitian lanjutan dengan pengambilan sampel dari berbagai senter laboratorium patologi di Bali sehingga hasil dapat mewakili populasi akseptor kontrasepsi hormonal di Bali.

\section{UCAPAN TERIMA KASIH}

Kami mengucapkan terima kasih kepada semua pihak yang telah berkontribusi terhadap pelaksanaan penelitian ini, diantaranya rekan ahli patologi RSUD Sanjiwani, RSUD Karangasem dan kepala instalasi laboratorium Balimed Denpasar. Terima kasih juga diucapkan kepada Dekan Fakultas Kedokteran dan Ilmu Kesehatan Universitas Warmadewa yang telah memberikan izin untuk melakukan penelitian.

\section{DAFTAR PUSTAKA}

1. Anonim. 2009. Reproductive health Indicator: World Health Organization. Geneva. pp. 9-13

2. Badan Kependudukan dan Keluarga Berencana Nasional (BKKBN). 2007. Buletin Program KB Nasional. Direktorat Pelaporan dan Statistik BKKBN.Jakarta. pp 2-8 
3. Badan Kependudukan dan Keluarga Berencana Nasional (BKKBN). 2011. Laporan Umpan Balik Hasil Pelaksanaan Subsistem Pencatatan dan Pelaporan Pelayanan Kontrasepsi. Direktorat Pelaporan dan Statistik BKKBN. Jakarta. pp 8-11

4. Bekker, E. 2015. Connection Between Chronic Yeast Infection And Hormonal Imbalance. Modpathol Journal. 5(3). 1-12

5. Casari, E. 2010. Gardnerella, Trichomonas vaginalis, Candida. $M i$ crobio J. 4. 1-6

6. Cheng, G; Yeater, KM; Hoyer, LL. 2006. Cellular and Molecular Biology of Candida Albicans Estrogen Response; Eucaryotic Cell American Society for Microbiology. Vol 5. 180190

7. Chrousos, GP.2007. The Gonadal Hormone and Inhibitors on Katzung Basic and Clinical Pharmacology. $10^{\text {th }}$ ed. The McGraw-Hill Co. Inc. Philadelphia. pp.664-71

8. Dhont, M. 2010. History of Oral Contraception. The European journal of Contraception and Reproductive Health Care. 15(52).15-18

9. Ekpenyong ,CE, Inyang-Etoh EC, akpan UP, Ibu JO, Daniel NE. 2012. Recurrent Vulvovaginal Candidiosis Among Young Women In South Eastern Nigeria; The role of Lifestyle and Health Care Practices; Int J STD AIDS.23(10). 704-9

10. Hamad, W. 2014. Estrogen Treatment Predisposes to Severe And Persistent Vaginal Candidiasis in Diabetic Mice. BioMed Central Journal of Diabetes and Metabolic Disorders. 12(10). 1-7

11. Infodatin, 2014. Pusat Data dan Informasi Kementerian Kesehatan. Jakarta. pp.1-6

12. Kiley, J, Hammond, C. 2007. Combined Oral Contraceptives; A Comprehensive Review. Clin. Obst. Gyn, 50(2). 868-77

13. Shahinfar, S., Nemanpour, B. 2016. The Relationship Between Contraceptive methods and Common Vaginal
Infections. Women's health Bull. Inpress e40793. Pp. 1-5.

14. Solomon C., Nayar. R. 2004. The Bethesda System for Reporting Cervical Cytology. Springer. pp 1-11

15. Susilowati, E. 2011. KB Suntik 3 Bulan dengan Efek Samping Gangguan Haid dan Penanganannya. Semarang. pp.1-8

16. Trussell, J. 2007. Contraceptive Efficacy. In Hatcher, R.A., et al; Contraceptive Technology; Ardent Media. New York. pp 1-12

17. Varney, Hellen et al. 2006. Buku Ajar Asuhan Kebidanan.Jakarta. 4(1). 2031

18. Wagner, RJ. 2012. Probiotic Lactobacillus and Estrogen effect on Vaginal Epithelial Gene Expression Responses to Candida Albicans. $J$ Biomed Sci. 5(2).19-58

19. Yusuf, MD., et al. 2007. Evaluation of the Effect of Contraceptives on Prevalence of Candida Species on Vaginal Candidiasis in Dhaka, Bangladesh. Bangladesh J med Microbiol. 01 (02). 61-64

20. Widodo, F.Y. 2014. Efek Pemakaian Kontrasepsi Kombinasi Terhadap Kadar Glukosa Darah. Surabaya. pp 1 $-9$

21. Wiknjosastro, H. 2007. Ilmu Kandungan. Yayasan Bina Pustaka. Jakarta. pp 534-575

22. Sari, N. M. (2013). Tingkat Pengetahuan Wanita Usia Subur (WUS) Tentang Persiapan Kehamilan Di Puskesmas Miri Sragen.

23. Anindita, W. dan S. M. (2006). Faktor Risiko Kejadian Kandidiasis Vaginalis pada Akseptor KB. The Indonesian Journal of Public Health, 3, 24-28.

24. Musdalifah, Muksen Sarake, R. (2013). Faktor Yang Berhubungan Dengan Pemilihan Kontrasepsi Hormonal Pasutri Di Wilayah Kerja Puskesmas Lampa Kecamatan Duampanua Kabupaten Pinarang 2013. Jurnal Fakultas Keshatan Masyarakat Universitas Hasanduin, 1, 1-13.

25. Ramadhan, G. S., \& Mardijana, A. 
(2017). Perbedaan Tingkat Kecenderungan Depresi pada Akseptor Berbagai Jenis Kontrasepsi Hormonal di Puskesmas Sumbersari Kabupaten Jember ( The Difference of Depression Tendency Level on User of Several Hormonal Contraception Types in Sumbersari Primary Health, 5(1), 25-29

26. Sety, L. M. (2014). Jenis Pemakaian Kontrasepsi Hormonal. Jurnal Kesehatan, 5, 60-66. 